\title{
Variability of Cetacean Distribution and Habitat Selection in the Alaskan Arctic, Autumn 1982-91
}

\author{
SUE E. MOORE 1
}

(Received 25 November 1999; accepted in revised form 5 July 2000)

\begin{abstract}
Ten years (1982-91) of autumn sighting data from aerial surveys offshore northern Alaska were analyzed to investigate variability in cetacean distribution and habitat selection. Habitat selection indices were calculated for bowhead, white, and gray whales in heavy, moderate, and light ice conditions; and for high, moderate, and low transport (inflow) conditions at Bering Strait. Bowhead whales selected shallow inner-shelf waters during moderate and light ice, and deeper slope habitat in heavy ice conditions $\left(\chi^{2}, p<0.05-0.001\right)$. White whales selected slope habitat $\left(\chi^{2}, p<0.001\right)$, and gray whales selected coastal/shoal and shelf/trough habitat $\left(\chi^{2}, p<0.025-0.001\right)$, in all ice conditions. In the Alaskan Beaufort Sea, bowheads selected shelf waters and white whales chose slope waters, without regard to transport conditions $\left(\chi^{2}, p<0.01-0.001\right)$. In the northern Chukchi Sea, gray whales selected coastal/shoal habitat in high transport conditions $\left(\chi^{2}, p<0.005\right)$, and shelf/trough habitat $\left(\chi^{2}, p<0.001\right)$ during moderate and low transport conditions. Variability in distribution and habitat selection among these species is likely linked to prey availability at dissimilar trophic levels, although this hypothesis has yet to be rigorously tested.
\end{abstract}

Key words: Alaska, Arctic, Beaufort Sea, bowhead whale, Chukchi Sea, gray whale, habitat selection, white whale

RÉSUMÉ. Des données d'observation réalisées en automne sur dix années (1982-1991) grâce à des relevés aériens au large de l'Alaska septentrional ont été analysées dans le cadre de recherches sur la variabilité dans la distribution des cétacés et la sélection de leur habitat. On a calculé les indices de sélection de l'habitat pour la baleine boréale, la baleine blanche et la baleine grise de Californie dans des conditions de glace épaisse, modérée et mince; et pour des conditions de transport (courants de déversement) important, moyen et faible dans le détroit de Béring. La baleine boréale choisissait des eaux peu profondes de l'intérieur du plateau continental durant les conditions de glace modérée et mince, et un habitat plus profond sur la pente durant des conditions de glace épaisse $\left(\chi^{2}, p<0,05-0,001\right)$. La baleine blanche choisissait l'habitat sur la pente $\left(\chi^{2}, p<0,001\right)$ et la baleine grise choisissait l'habitat côtier/de hauts-fonds et celui du plateau/des fossés $\left(\chi^{2}, p<0,025-0,001\right)$, quelles que soient les conditions de glace. Dans la partie alaskienne de la mer de Beaufort, la baleine boréale choisissait les eaux du plateau et la baleine blanche celles de la pente, abstraction faite des conditions de transport $\left(\chi^{2}, p<0,01-0,001\right)$. Dans la partie septentrionale de la mer des Tchouktches, la baleine grise choisissait un habitat côtier/de hauts-fonds dans des conditions de transport important $\left(\chi^{2}, p<0,005\right)$ et un habitat de plateau/de fossés $\left(\chi^{2}, p<0,001\right)$ dans des conditions de transport allant de moyen à faible. La variabilité dans la distribution et la sélection de l'habitat parmi ces espèces est probablement liée à la disponibilité des proies à des niveaux trophiques dissemblables, bien que cette hypothèse doive encore faire l'objet de tests approfondis.

Mots clés: Alaska, Arctique, mer de Beaufort, baleine boréale, mer des Tchouktches, baleine grise de Californie, sélection de l'habitat, baleine blanche

Traduit pour la revue Arctic par Nésida Loyer.

\section{INTRODUCTION}

The Arctic Ocean has experienced a marked warming trend over the last century (Overpeck et al., 1997), with consistent, but not uniform, decreases in ice extent described for the last three decades (Maslanik et al., 1996; Martin et al., 1997). Marked interannual variation in salinity has also been reported (e.g., Bjornsson et al., 1995; Roach et al., 1995), although without a clear trend toward, or against, freshening of Arctic waters. The effects of climate change are predicted to be amplified in the Arctic because of positive feedback mechanisms associated with deterioration of snow-ice albedo (Overpeck et al., 1997; Aagaard et al., 1999). Given this likely amplification, it would be useful to identify Arctic species that could serve as indicators of environmental change. Marine mammals are considered good candidates for this role because they are positioned as apex predators (Ainley and DeMaster, 1990); the response of some species to changes in sea ice availability can be observed (DeMaster and Davis, 1995; Stirling, et al., 1999); and their importance as a subsistence resource encourages monitoring of population dynamics

\footnotetext{
${ }^{1}$ Scripps Institution of Oceanography/SAIC, Maritime Services Division, 3990 Old Town Avenue, \#105A, San Diego, California 92110, U.S.A.; present address: NOAA/NMFS/AFSC, National Marine Mammal Laboratory, 7600 Sand Point Way NE, Seattle, Washington 98115, U.S.A.; sue.moore@noaa.gov

(C) The Arctic Institute of North America
} 
(e.g., Zeh et al., 1993). Specifically, bowhead whales (Balaena mysticetus), ringed seals (Phoca hispida), and white whales (Delphinapterus leucas) have been suggested as indicator species (Tynan and DeMaster, 1997). To this list I would add gray whales (Eschrichtius robustus), given their unique role as perturbators of the benthos in Arctic and Subarctic waters (Oliver and Slattery, 1985; Feder et al., 1994).

Bowhead whales, white whales, and gray whales occupy dissimilar habitats offshore northern Alaska, which Moore and DeMaster (1997) provisionally described by average differences in bathymetry and ice cover. As a refinement to simply comparing differences in average measures of habitat features, Moore et al. (2000) calculated habitat selection ratios for the three species in summer and autumn. While descriptive in nature, the indices of habitat selection are based on quantification of survey effort and represent a key first step towards estimating resource selection by animals (Manly et al., 1993). These indices indicate that, in summer, bowhead whales selected continental slope waters and moderate ice conditions; white whales selected slope and basin waters and moderate to heavy ice conditions; and gray whales selected coastal/ shoal waters that were usually ice-free. In autumn, bowheads shifted to shallow inner-shelf waters and light to ice-free conditions; white whales selected outer shelf and slope waters in moderate to heavy ice cover; and gray whales selected coastal/shoal and trough habitats in light to ice-free conditions. Habitat differences among species were significant in both summer and autumn (ANOVA $\mathrm{F}>28, p<0.0001)$. This habitat partitioning is likely associated with distinct differences in preferred prey and foraging strategies among the three species (see Moore et al., 2000), although this hypothesis has not been tested.

The calculation of autumn habitat selection ratios in Moore et al. (2000) did not address variability in cetacean distribution in relation to changes in environmental conditions. However, for whales to be useful as indicators of environmental change in the Arctic, as suggested in Tynan and DeMaster (1997), some baseline for modeling this variability is required. As a first step toward this type of modeling, this paper describes variable distribution and habitat selection among bowhead, white, and gray whales calculated for different conditions of sea ice cover and inflow (hereafter, transport) at Bering Strait. As in Moore et al. (2000), cetacean distribution and habitat selection indices were derived from ten years (1982-91) of sighting data from aerial surveys conducted offshore northern Alaska and funded by the Minerals Management Service (MMS) of the U.S. Department of the Interior.

\section{Oceanographic Variability}

An overview of physical oceanography offshore northern Alaska is provided in Moore and DeMaster (1997) and Moore et al. (2000). Ice cover and transport (i.e., in-flow) at Bering Strait are two aspects of Alaskan Arctic physical oceanography that may affect cetacean distribution and habitat selection. Sea ice affects productivity in the Arctic (Smith and Nelson, 1985; Smith and Sakshaug, 1990; Smith and Schnack-Schiel, 1990) and can also act as a physical barrier to migrating animals. Transport at Bering Strait provides an advective pathway for nutrients and zooplankton between the northern Bering, Chukchi, and western Beaufort Seas (Grebmeier and Barry, 1991; Niebauer and Schell, 1993) and, via the Beaufort Undercurrent, possibly as far as the eastern Alaskan Beaufort Sea (Aagaard, 1984; Fissel et al., 1987). Because cetaceans are apex predators in the short food webs common to the Arctic (Ainley and DeMaster, 1990), physical factors that influence productivity and prey availability will likely influence habitat selection. Alternatively, bathymetrically channeled currents may provide migratory cues to animals.

Over the course of the study, sea ice cover varied from years when the Alaskan Beaufort and northern Chukchi Seas remained ice covered to years when the ice retreated nearly $170 \mathrm{~km}$ offshore. If ice affects cetacean distribution, either as an affiliate of prey or as an impediment to migration, differences in distribution among years ranked as heavy, moderate, and light in ice cover should be apparent. Transport at Bering Strait also exhibited strong interannual variation during the study period, with mean transport ranging from 0.61 to $0.96 \mathrm{~Sv}$ (Roach et al., 1995). If transport affects cetacean distribution, either by influencing foraging opportunities via advection of prey or enhancement of productivity, or by providing migration cues via distinctive water mass qualities, differences in distribution among years ranked as high, moderate, and low in transport should be identifiable. Because both ice cover and transport are wind forced (Niebauer, 1988; Roach et al., 1995), they are not independent variables. However, when study years were ranked into heavy/high vs. moderate vs. light/low categories for analyses, correspondence between data sets was incomplete, so distribution and habitat selection were examined separately for years pooled by (1) ranks of sea ice cover and (2) transport at Bering Strait.

\section{METHODS}

The study area, survey protocol, and statistical approach are described in Moore et al. (2000). Specifically, habitat selection was tested by species and oceanographic parameter via chi-square analysis and the calculation of habitat selection ratios (Manly et al., 1993). One note of caution is needed: the chi-square test generally requires that expected frequencies be five or more, and this was rarely the case for the northern Chukchi Sea analyses (see Tables 4 and 6). Manly et al. (1993) suggest that the test may still be valid when the condition is not met, but results must be treated with some reservation. Because much of the Chukchi Sea falls into the 36-50 m depth regime, most of the survey effort and sightings occur there. However, 
TABLE 1. Interannual variability of sea ice condition and mean transport at Bering Strait for 1982-91. Ice conditions from United States Navy/NOAA Joint Ice Center (Navy/NOAA, 1992); transport from Roach et al. (1995).

\begin{tabular}{lccccc}
\hline \hline YEAR & $\begin{array}{c}\text { Ice-free } \\
(\text { days })^{1}\end{array}$ & $\begin{array}{c}50 \% \text { ice } \\
(\text { days })^{2}\end{array}$ & Ice Rank $^{3}$ & $\begin{array}{c}\text { Transport } \\
(\text { Sv })\end{array}$ & $\begin{array}{c}\text { Transport } \\
\text { Rank }\end{array}$ \\
\hline 1982 & 21 & 69 & 4 & 0.80 & 8 \\
1983 & 0 & 21 & 10 & 0.64 & 3 \\
1984 & 21 & 42 & 7 & 0.69 & 5 \\
1985 & 22 & 52 & 6 & 0.74 & 7 \\
1986 & 30 & 58 & 3 & 0.71 & 6 \\
1987 & 35 & 59 & 5 & 0.61 & 1 \\
1988 & 0 & 32 & 9 & 0.63 & 2 \\
1989 & 34 & 95 & 2 & 0.96 & 10 \\
1990 & 75 & 105 & 1 & 0.83 & 9 \\
1991 & 0 & 46 & 8 & 0.68 & 4 \\
\hline \hline
\end{tabular}

${ }^{1}$ Number of days with ice-free waters between Pt. Barrow and Prudhoe Bay.

${ }^{2}$ Number of days with $50 \%$ ice cover conditions between Pt. Barrow and Prudhoe Bay.

${ }^{3}$ study years re-scored from original ranks.

the Chukchi shelf is not a featureless plain; in fact, its topography plays a major role in channeling currents. Thus, the chi-square analysis is included here for completeness, to investigate cetacean use of shoal and trough features, although habitat selection results should indeed be viewed cautiously.

Overall survey effort consisted of 495 flights conducted in autumn (September and October). Sightings made during randomly derived transect legs are considered a random sample (Buckland et al., 1993) and are hereafter designated as transect-sightings (t-SI), each of which represents the location of one or several animals. The number of t-SI, not the total number of whales, was used in all analyses because extended circling to obtain "best estimates" of group size was seldom conducted.

Water depth and sea ice cover were the only two environmental features recorded on the same temporal and spatial scale as cetacean sightings, restricting habitat selection analyses to these two parameters. Post-survey stratification of the study area into bathymetric blocks (Moore et al., 2000: Fig. 4) provided a means to calculate survey effort $(\mathrm{t}-\mathrm{km})$ and cetacean sightings (t-SI) by depth regimes that correspond to broad patterns of current flow offshore Alaska (Moore et al., 2000: Table 1).

\section{Ranking Oceanographic Variability}

The United States Navy/NOAA Joint Ice Center (Navy/ NOAA, 1992) provided a particularly relevant overview of ice conditions within the entire study area because of its focus on maritime navigation in the Alaskan Chukchi and Beaufort Seas. A strong correlation $(\mathrm{r}=0.742, p<0.01)$ between Navy/NOAA (1992) records and the year-rank based on ice conditions observed during surveys (calculated as survey effort [t-km] associated with heavy
[>70\%] ice cover) further supported the use of the published ice-ranks for this analysis. The survey years 1982 to 1991 were ranked from 7 to 34 of the 39 years (1953-91) in the Navy/NOAA records. They were subsequently rescored from 1-10 relative to one another (Table 1).

Modeling of the dynamic interannual variability of transport at Bering Strait (e.g., Aagaard et al., 1985; Coachman and Aagaard, 1988) has been based on winds, with direct measurements across the entire strait possible only in recent years (Roach et al., 1995). Interannual differences in mean transport were pronounced during the study period, but generally fell below the long-term annual mean of $0.83 \mathrm{~Sv}$ (Table 1). Transport generally declined each year from 1982 to 1988 , then rebounded to the third highest estimate in 50 years in $1989(0.96 \mathrm{~Sv})$. A year of 'average' transport (0.83 Sv) followed in 1990. Transport then dropped off to below-average levels $(0.68 \mathrm{~Sv})$ in 1991.

Years were grouped into three ice cover categories (heavy, moderate, and light), and three transport categories (high, moderate, and low) based upon ranks. During the three years of heavy ice conditions $(1983,1988$, and 1991), the sea route between Point Barrow and Prudhoe Bay was never ice-free. During the three years of light ice conditions $(1986,1989$, and 1990), ice retreated 130 to 167 $\mathrm{km}$ (70 to 90 nautical miles) from Point Barrow, and the sea route was ice-free for 30 to 75 days. In moderate ice years $(1982,1984,1985$, and 1987), ice retreated 19 to 158 $\mathrm{km}$ (10 to 85 nautical miles), and the sea route was ice-free for 21 to 35 days. Years of comparatively heavy ice conditions occurred at five- and three-year intervals, a finding similar to the results of a far more comprehensive study of ice severity cycles (Mysak and Manak, 1989). In low transport years $(1983,1987,1988)$ inflow at Bering Strait was roughly $0.2 \mathrm{~Sv}$ below the long-term mean, while in high transport years $(1982,1989,1990)$, transport nearly met or exceeded the long-term mean. During moderate transport years $(1984,1985,1986,1991)$, inflow was below the long-term mean by roughly $0.1 \mathrm{~Sv}$.

Because both ice cover and transport are wind-forced, it was not surprising to find a significant negative relation$\operatorname{ship}(\mathrm{r}=-0.745, p<0.01)$ between ice and transport data ranked for years 1982-91 (Table 1). In other words, transport rank accounted for roughly $55 \%$ of the ice severity rank variability, with light ice conditions generally coincident with high transport. The relationship is not a simple one, however. Northward flow at Bering Strait is primarily driven by southerly winds (Roach et al., 1995), while ice cover offshore northern Alaska is principally affected by winds from the northwest (Muench et al., 1991). Transport reversals (southward flow) at Bering Strait and shoreward of Barrow Canyon are associated with sustained northerly winds and winds from the eastnortheast, respectively (Aagaard et al., 1985; Johnson, 1989), while easterly winds along Alaska's north slope, combined with the Coriolis force, generally pull ice offshore. Although winds offshore northern Alaska are primarily associated with the position and strength of the 
Aleutian Low, high- and low-pressure cells over Siberia and northern Canada also exert a strong influence (Niebauer, 1988). While the complex interaction of these Northern Hemisphere weather patterns, and their connection with the El Niño-Southern Oscillation, have a demonstrable effect on ice conditions in the eastern Bering Sea (e.g., Niebauer and Day, 1989), this model has not been extended to waters north of the Bering Strait.

\section{Effects of Water Depth and Sea Ice on Whale Detection during Aerial Surveys}

Clearly, the results of habitat selection analyses can be skewed if the likelihood of detecting a surfaced whale is affected by water depth or sea surface ice cover. Unfortunately, no rigorous testing for observer detection bias (e.g., Marsh and Sinclair, 1989) was done during the 1982-91 surveys. Detection distance was the only measure available to investigate sighting bias, and results were somewhat equivocal (Moore, 1997). There was a significant negative association between ice cover and sighting distance for bowhead whales $(\mathrm{t}=-2.21, p=0.028)$, but these same variables had a very strong positive association for white whales $(\mathrm{t}=4.15, p=0.00004)$. Gray whales were seldom seen in ice, and detection distances were not significantly affected.

Water depth did not affect sighting distance for bowhead, white, or gray whales. Group size was positively associated with sighting distance for all species, but was not correlated with specific ice cover or depth habitat. Restricting analyses to transect-sightings (t-SI) mediated the biases related to ice cover because t-SI represent a random sampling over all available conditions (i.e., bias related to surveys focused on areas of open water or heavy ice was eliminated). Thus, although analyses of detection distance provided only an index of visibility bias, the association of cetacean sightings with particular ice cover habitats should be interpreted with those results in mind. For example, the negative bias of bowhead detection distance by ice cover suggests that high selection ratios for light ice or open water habitats should be interpreted with caution because of detection bias for those habitats. Similarly, the positive bias of white whale detection distance with ice cover may amplify selection ratios for heavy ice habitat for that species.

\section{RESULTS}

\section{Habitat Variability with Ice Cover}

In the Alaskan Beaufort Sea, bowhead whales were seen far more often than expected in inner shelf waters during moderate and light ice cover conditions, but not in heavy ice conditions (Table 2). Although significant ( $p<$ $0.05)$, the association of bowheads with outer shelf and slope habitat in heavy ice conditions was less sharply defined than their selection of inner shelf habitat $(p<$ 0.001 ) in light ice conditions (Fig. 1). Standardized habitat selection ratios suggest a graded response to ice cover, with highest indices calculated for inner shelf habitat during light ice conditions $\left(\mathrm{B}_{4}=0.56\right)$, a slightly lower ratio during moderate ice conditions $\left(\mathrm{B}_{4}=0.50\right)$, dropping to a comparatively low ratio $\left(\mathrm{B}_{4}=0.25\right)$ in heavy ice conditions (Table 3 ). For slope habitat, the selection ratio during heavy ice conditions $\left(\mathrm{B}_{4}=0.30\right)$ was four to five times that calculated for that habitat in light or moderate ice conditions. But for outer shelf habitat, the ratio was

TABLE 2. Variability of bowhead whale $(\mathrm{BH})$ and white whale $(\mathrm{WW})$ transect sightings (t-SI) with ice condition rank, by depth regime, in the Alaskan Beaufort Sea. Ice conditions ranked from Navy/NOAA (1992).

\begin{tabular}{|c|c|c|c|c|c|c|c|}
\hline \multirow[t]{2}{*}{ Ice Condition [years] } & \multirow[t]{2}{*}{ Depth Regime (m) } & \multirow[t]{2}{*}{ Effort $(\mathrm{t}-\mathrm{km})$} & \multicolumn{2}{|c|}{ Observed (t-SI) } & \multicolumn{3}{|c|}{ Expected } \\
\hline & & & $\mathrm{BH}$ & WW & & $\mathrm{BH}$ & WW \\
\hline Heavy & $>2000$ & 7031 & 3 & 63 & & 11 & 39 \\
\hline \multirow[t]{3}{*}[1983,1988,1991]{} & $201-2000$ & 10600 & 19 & 126 & & 17 & 59 \\
\hline & $51-200$ & 10115 & 23 & 62 & & 16 & 57 \\
\hline & $\leq 50$ & 18781 & 28 & 7 & & 29 & 103 \\
\hline \multirow[t]{2}{*}{ Total } & & 46527 & 73 & 258 & & 73 & 258 \\
\hline & & & & & $\begin{array}{l}\chi^{2}= \\
p<\end{array}$ & $\begin{array}{l}9 \\
0.05\end{array}$ & $\begin{array}{l}181 \\
0.001\end{array}$ \\
\hline Moderate & $>2000$ & 6869 & 2 & 17 & & 18 & 18 \\
\hline \multirow[t]{3}{*}[1982,1984,1985,1987]{} & $201-2000$ & 11774 & 5 & 83 & & 32 & 30 \\
\hline & $51-200$ & 14849 & 46 & 62 & & 41 & 38 \\
\hline & $\leq 50$ & 34155 & 133 & 13 & & 95 & 89 \\
\hline \multirow[t]{3}{*}{ Total } & & 67647 & 186 & 175 & & 186 & 175 \\
\hline & & & & & $\chi^{2}=$ & 53 & 173 \\
\hline & & & & & $\ddot{p}<$ & 0.001 & 0.001 \\
\hline Light & $>2000$ & 2808 & 0 & 8 & & 13 & 7 \\
\hline \multirow[t]{3}{*}[1986,1989,1990]{} & $201-2000$ & 6175 & 5 & 52 & & 29 & 15 \\
\hline & $51-200$ & 6443 & 27 & 16 & & 29 & 15 \\
\hline & $\leq 50$ & 19775 & 130 & 8 & & 91 & 47 \\
\hline \multirow[t]{3}{*}{ Total } & & 35201 & 162 & 84 & & 162 & 84 \\
\hline & & & & & $\chi^{2}=$ & 50 & 124 \\
\hline & & & & & $p<$ & 0.001 & 0.001 \\
\hline
\end{tabular}



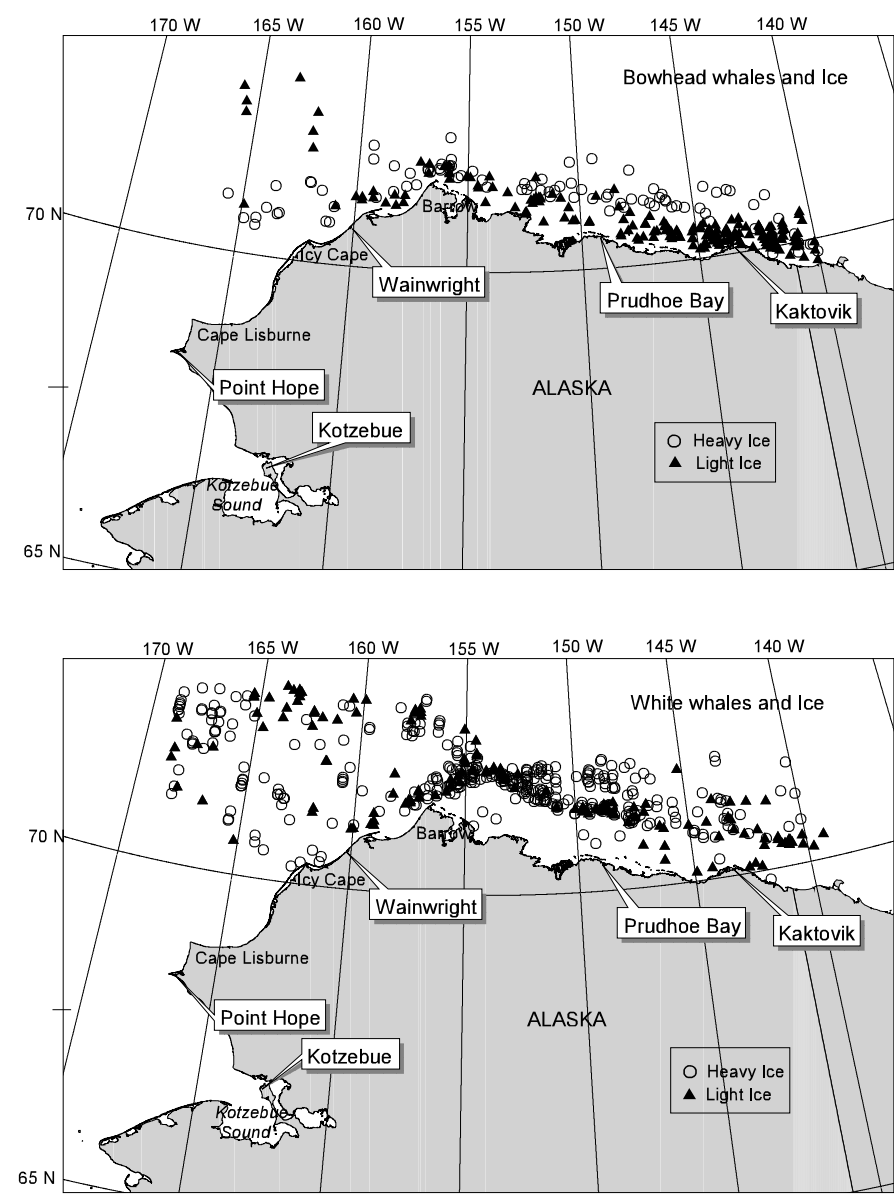

FIG. 1. Bowhead and white whale autumn distribution in light and heavy ice conditions.

nearly identical $\left(\mathrm{B}_{3}=0.37\right.$ to 0.40$)$ across the three ice condition categories.

White whales were seen more often than expected in slope habitat in the Alaskan Beaufort Sea, no matter the ice conditions (Table 2; Fig. 1). Standardized habitat selection ratios support the consistency of white whale association with slope habitat, although responses to ice conditions were graded, as for bowheads (Table 3 ). The highest slope selection ratio $\left(B_{2}=0.58\right)$ was associated with light ice conditions, and the lowest ratio $\left(B_{2}=0.44\right)$ with heavy ice years. Conversely, selection ratios indicated that white whales avoid inner shelf habitat in all ice conditions $\left(B_{4} \leq 0.03\right)$.

In the northern Chukchi Sea, bowheads were associated with specific depth habitat only in light ice conditions (Table 4). The selection of coastal habitat during light ice years $(p<0.005)$ seems to be an extension of the inner shelf distribution exhibited by bowheads in the Alaskan Beaufort Sea, combined with an occupation of offshore shoal habitats that might not be available to whales when ice conditions are moderate or heavy (Fig. 1). The high standardized ratio $\left(\mathrm{B}_{4}=0.82\right)$ reflected the bowheads' preference for coastal/shoal habitat in light ice conditions (Table 5). Although standardized ratios were also relatively high for shelf/trough habitat in moderate and heavy ice conditions $\left(B_{2}=0.64\right.$ and 0.67$)$, chi-square statistics
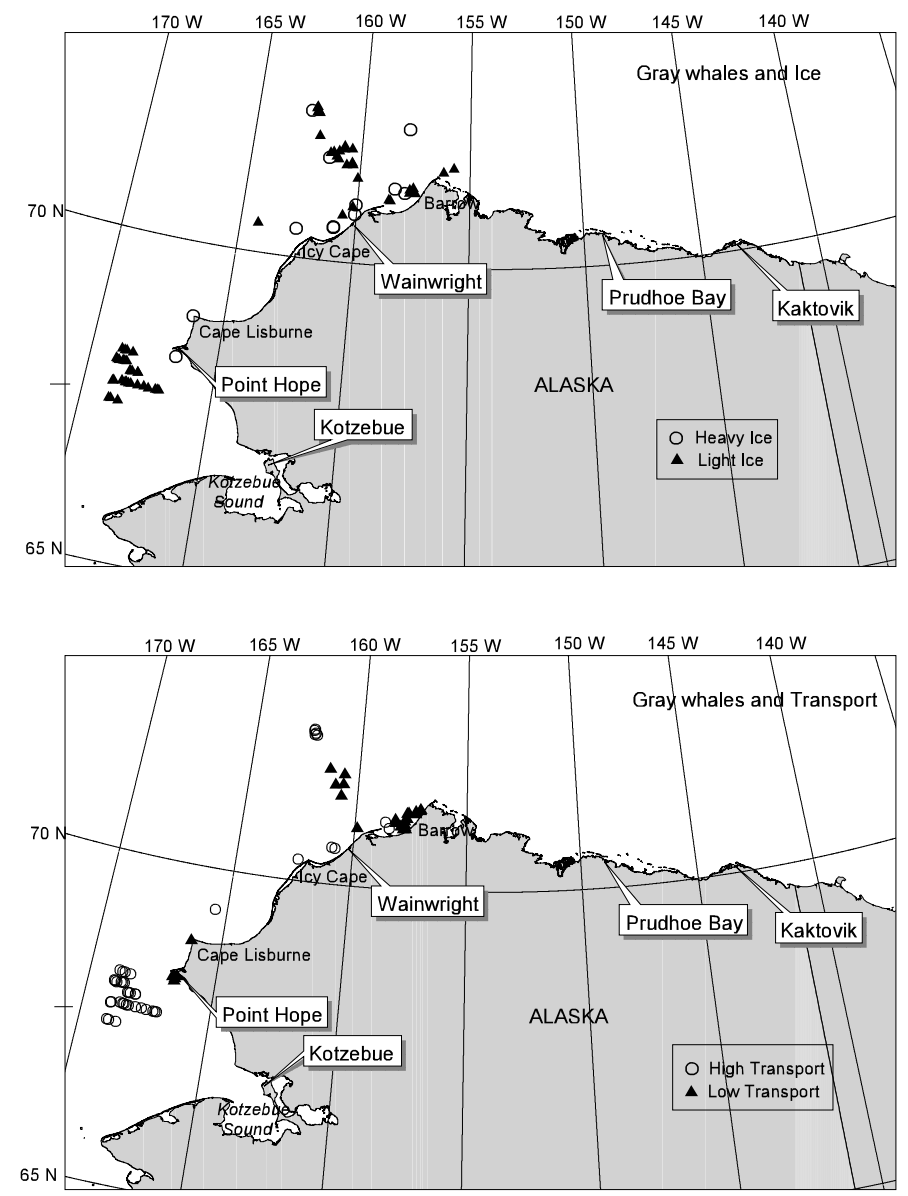

FIG. 2. Gray whale autumn distribution in light and heavy ice conditions, and in low and high transport conditions.

calculated independently for these ratios indicated significant habitat selection in heavy $\left(\chi^{2}=5.73, p<0.025\right)$, but not in moderate $\left(\chi^{2}=1.84, p<0.25\right)$ ice conditions. In moderate and heavy ice years, bowhead distribution was aligned with shelf/trough habitat in the Barrow Canyon axis (Fig. 1), a region where wind and inflow of Alaskan Coastal Water generate an open-water lead each spring and likely influence ice in a similar manner in autumn.

White whales were seen more often than expected in slope habitat during heavy and light ice years, but not during moderate ice years in the northern Chukchi Sea (Table 4). The lack of white whale sightings in slope habitat during years of moderate ice conditions is likely due to insufficient survey effort $\left(\mathrm{pE}_{1}=0.01\right)$, and therefore probably does not represent a true difference in habitat selection. Indeed, standardized selection ratios were highest for slope habitat $\left(B_{1}=0.49\right.$ and 0.61$)$ whenever survey effort included those areas (Table 5). In heavy ice conditions, white whales selected all habitats other than slope nearly uniformly. During moderate ice years, white whales selected shelf/trough waters nearly twice as often as any other bathymetric habitat, although the standardized ratio $\left(\mathrm{B}_{2}=0.50\right)$ was not statistically significant $\left(\chi^{2}=0.89, p<\right.$ $0.50)$. In contrast to bowheads, white whales avoided coastal/shoal habitat during light ice conditions. 
TABLE 3. Alaskan Beaufort Sea depth habitat selection ratios $\left(\mathrm{w}_{\mathrm{i}}\right)$ and standardized ratios $\left(\mathrm{B}_{\mathrm{i}}\right)$ for bowhead and white whales in ice conditions ranked as heavy, moderate, and light.

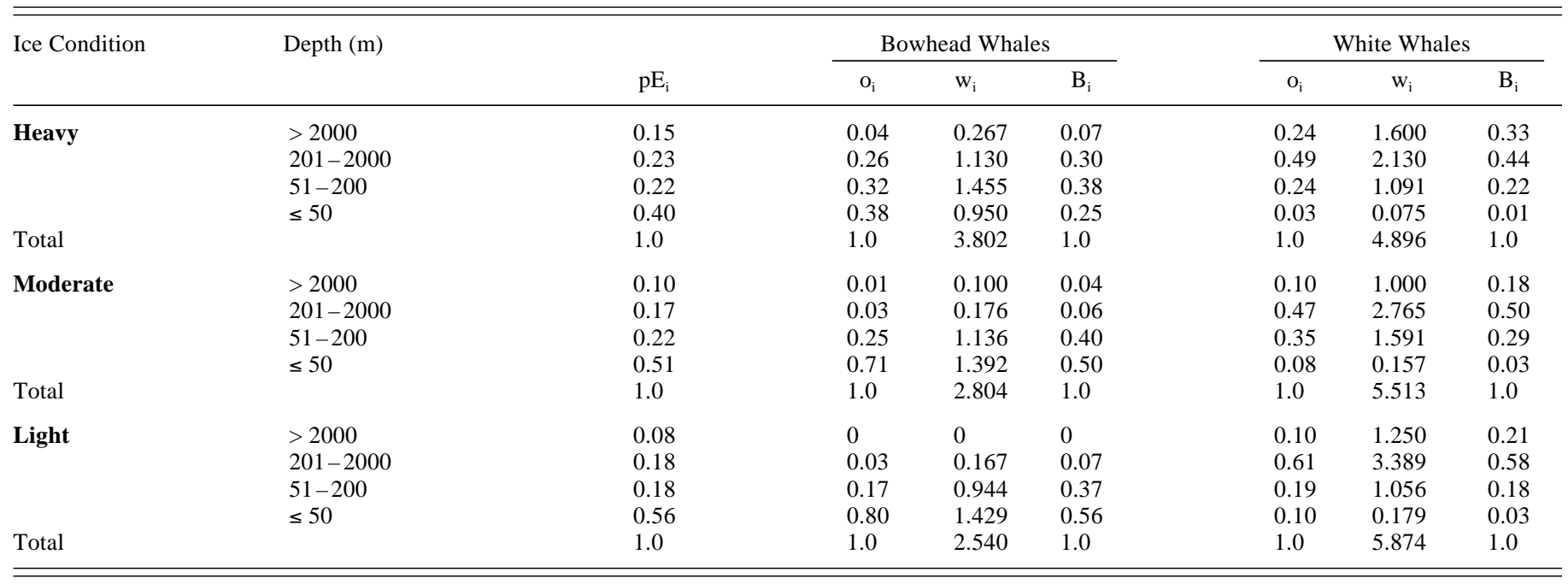

TABLE 4. Variability of bowhead whale (BH), white whale (WW), and gray whale (GW) transect sightings (t-SI) with ice condition rank, by depth regime, in the northern Chukchi Sea. Ice conditions ranked from Navy/NOAA (1992).

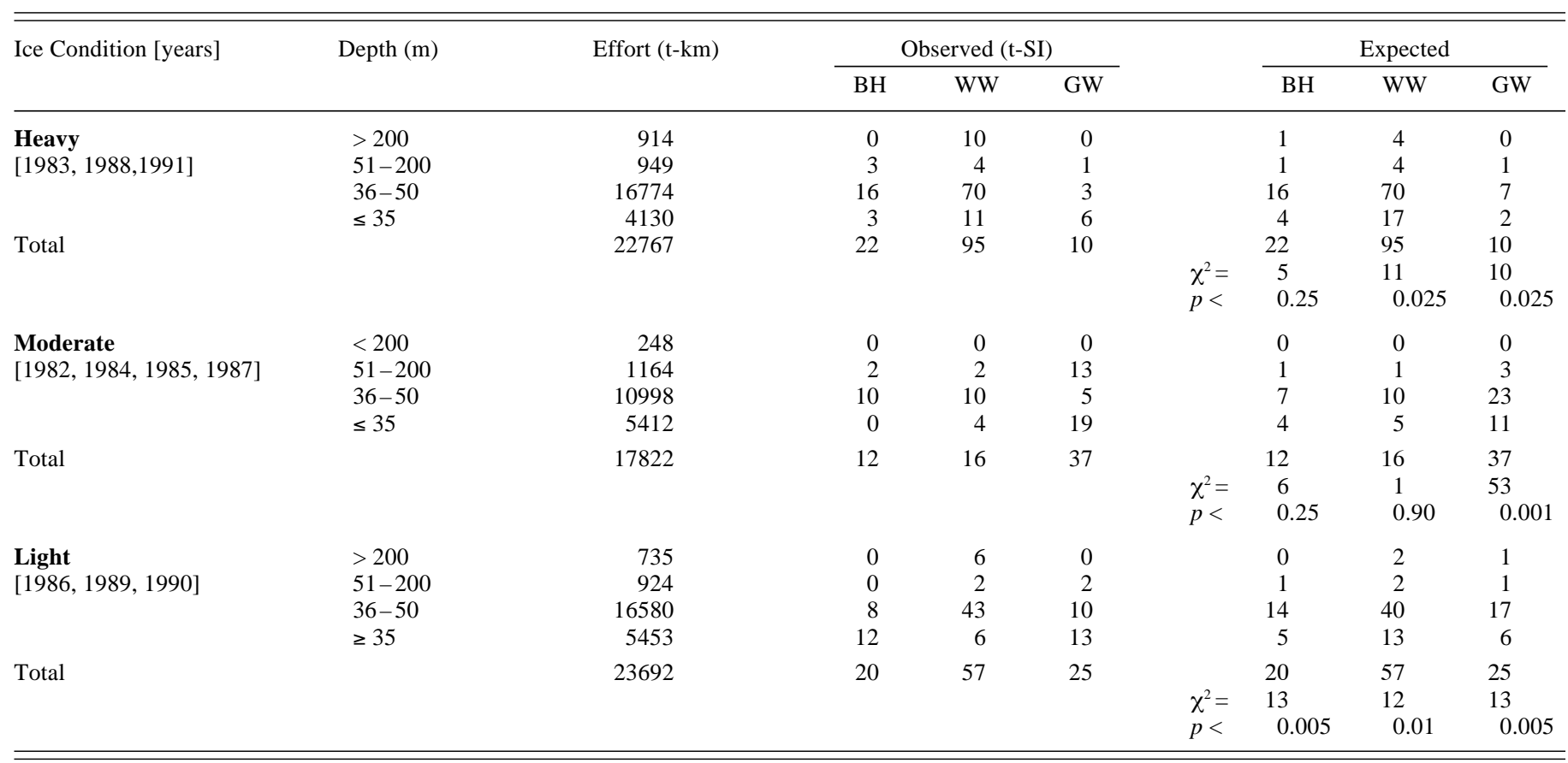

Gray whales were seen more often than expected in coastal/shoal habitat in all ice conditions in the northern Chukchi Sea (Table 4). Distribution during heavy ice conditions was sparse and generally confined to coastal waters near Wainwright, with only three sightings offshore near shoal areas (Fig. 2). Conversely, during light ice years, clusters of gray whale t-SI occurred in coastal and offshore shoal habitat. Standardized selection ratios were similar for coastal/shoal and shelf/trough habitat in years of heavy and light ice conditions, while in moderate ice years, ratios suggest that gray whales selected shelf/ trough waters $\left(B_{2}=0.72\right)$ nearly three times more often than coastal/shoal habitat $\left(\mathrm{B}_{4}=0.25\right.$; Table 5).
Comparison of selection ratios among species in the northern Chukchi Sea suggests that gray and bowhead whale habitats may overlap somewhat, in shelf/trough areas in heavy ice years and in coastal/shoal habitat in years of light ice cover (Table 5). Conversely, habitat partitioning between white whales and the two mysticete species seems distinct, in years of both heavy and light ice conditions: white whales are consistently associated with slope habitat. Although comparison of standardized selection ratios among species in moderate ice years indicates all three species prefer shelf/trough waters, the ratios for bowhead and white whales were not statistically significant. 
TABLE 5. Northern Chukchi Sea depth habitat selection ratios $\left(\mathrm{w}_{\mathrm{i}}\right)$ and standardized ratios $\left(\mathrm{B}_{\mathrm{i}}\right)$ for bowhead, white, and gray whales in ice conditions ranked as heavy, moderate, and light.

\begin{tabular}{|c|c|c|c|c|c|c|c|c|c|c|c|}
\hline \multirow[t]{2}{*}{ Ice Condition } & \multirow{2}{*}{$\begin{array}{c}\text { Depth } \\
(\mathrm{m})\end{array}$} & \multirow[b]{2}{*}{$\mathrm{pE}_{\mathrm{i}}$} & \multicolumn{3}{|c|}{ Bowhead Whales } & \multicolumn{3}{|c|}{ White Whales } & \multicolumn{3}{|c|}{ Gray Whales } \\
\hline & & & $\mathrm{O}_{\mathrm{i}}$ & $\mathrm{w}_{\mathrm{i}}$ & $\mathrm{B}_{\mathrm{i}}$ & $\mathrm{O}_{\mathrm{i}}$ & $\mathrm{w}_{\mathrm{i}}$ & $\mathrm{B}_{\mathrm{i}}$ & $\mathrm{O}_{\mathrm{i}}$ & $\mathrm{w}_{\mathrm{i}}$ & $\mathrm{B}_{\mathrm{i}}$ \\
\hline \multirow[t]{4}{*}{ Heavy } & $>200$ & 0.04 & 0 & 0 & 0 & 0.10 & 2.500 & 0.49 & 0 & 0 & 0 \\
\hline & $51-200$ & 0.04 & 0.14 & 3.500 & 0.67 & 0.04 & 1.000 & 0.19 & 0.10 & 2.500 & 0.40 \\
\hline & $36-50$ & 0.74 & 0.72 & 0.973 & 0.18 & 0.74 & 1.000 & 0.19 & 0.30 & 0.405 & 0.06 \\
\hline & $\leq 35$ & 0.18 & 0.14 & 0.778 & 0.15 & 0.12 & 0.667 & 0.13 & 0.60 & 3.333 & 0.54 \\
\hline Total & & 1.0 & 1.0 & 5.251 & 1.0 & 1.0 & 5.167 & 1.0 & 1.0 & 6.238 & 1.0 \\
\hline \multirow[t]{4}{*}{ Moderate } & $>200$ & 0.01 & 0 & 0 & 0 & 0 & 0 & 0 & 0 & 0 & 0 \\
\hline & $51-200$ & 0.07 & 0.17 & 2.429 & 0.64 & 0.13 & 1.857 & 0.50 & 0.35 & 5.000 & 0.72 \\
\hline & $36-50$ & 0.62 & 0.83 & 1.339 & 0.36 & 0.62 & 1.000 & 0.27 & 0.14 & 0.226 & 0.03 \\
\hline & $\leq 35$ & 0.30 & 0 & 0 & 0 & 0.25 & 0.833 & 0.23 & 0.51 & 1.700 & 0.25 \\
\hline Total & & 1.0 & 1.0 & 3.768 & 1.0 & 1.0 & 3.690 & 1.0 & 1.0 & 6.926 & 1.0 \\
\hline \multirow[t]{4}{*}{ Light } & $>200$ & 0.03 & 0 & 0 & 0 & 0.11 & 3.667 & 0.61 & 0 & 0 & 0 \\
\hline & $51-200$ & 0.04 & 0 & 0 & 0 & 0.03 & 0.750 & 0.13 & 0.08 & 2.000 & 0.41 \\
\hline & $36-50$ & 0.70 & 0.40 & 0.571 & 0.18 & 0.75 & 1.071 & 0.18 & 0.40 & 0.571 & 0.12 \\
\hline & $\leq 35$ & 0.23 & 0.60 & 2.609 & 0.82 & 0.11 & 0.478 & 0.08 & 0.52 & 2.261 & 0.47 \\
\hline Total & & 1.0 & 1.0 & 3.180 & 1.0 & 1.0 & 5.966 & 1.0 & 1.0 & 4.832 & 1.0 \\
\hline
\end{tabular}

TABLE 6. Variability of bowhead whale (BH) and white whale (WW) transect sightings (t-SI) with transport rank, by depth regime, in the Alaskan Beaufort Sea. Annual transport ranked from Roach et al. (1995).

\begin{tabular}{|c|c|c|c|c|c|c|c|}
\hline \multirow[t]{2}{*}{ Transport [years] } & \multirow[t]{2}{*}{ Depth Regime (m) } & \multirow[t]{2}{*}{ Effort $(\mathrm{t}-\mathrm{km})$} & \multicolumn{2}{|c|}{ Observed (t-SI) } & & \multicolumn{2}{|c|}{ Expected } \\
\hline & & & $\mathrm{BH}$ & WW & & $\mathrm{BH}$ & WW \\
\hline High & $>2000$ & 2216 & 2 & 2 & & 14 & 4 \\
\hline \multirow{3}{*}[1982,1989,1990]{} & $201-2000$ & 3768 & 4 & 28 & & 22 & 6 \\
\hline & $51-200$ & 5758 & 30 & 14 & & 34 & 9 \\
\hline & $\leq 50$ & 17203 & 136 & 1 & & 102 & 26 \\
\hline \multirow[t]{3}{*}{ Total } & & 28945 & 172 & 45 & & 172 & 45 \\
\hline & & & & & $\chi^{2}=$ & 37 & 108 \\
\hline & & & & & $p<$ & 0.001 & 0.00 \\
\hline Moderate & $>2000$ & 7523 & 0 & 30 & & 17 & 26 \\
\hline \multirow[t]{3}{*}[1984,1985,1986,1991]{} & $201-2000$ & 12108 & 10 & 110 & & 30 & 44 \\
\hline & $51-200$ & 12536 & 43 & 70 & & 30 & 44 \\
\hline & $\leq 50$ & 32910 & 104 & 22 & & 80 & 118 \\
\hline \multirow[t]{3}{*}{ Total } & & 65077 & 157 & 232 & & 157 & 232 \\
\hline & & & & & $\chi^{2}=$ & 43 & 193 \\
\hline & & & & & $\hat{p}<$ & 0.001 & 0.001 \\
\hline Low & $>2000$ & 6969 & 3 & 56 & & 11 & 29 \\
\hline \multirow[t]{3}{*}[1983,1987,1988]{} & $201-2000$ & 12673 & 15 & 123 & & 21 & 55 \\
\hline & $51-200$ & 13113 & 23 & 56 & & 22 & 58 \\
\hline & $\leq 50$ & 22598 & 51 & 5 & & 38 & 98 \\
\hline \multirow[t]{3}{*}{ Total } & & 55353 & 92 & 240 & & 92 & 240 \\
\hline & & & & & $\chi^{2}=$ & 12 & 198 \\
\hline & & & & & $p<$ & 0.01 & 0.001 \\
\hline
\end{tabular}

\section{Habitat Variability with Transport at Bering Strait}

In the Alaskan Beaufort Sea, under all transport conditions, bowhead whales were seen more often than expected in inner shelf waters, and white whales appeared more often than expected in slope waters (Table 6). Distribution plots and standardized selection ratios indicate that transport had little effect on bowhead whale habitat selection (Fig. 3, Table 7). Conversely, white whale distribution was far broader in years of low transport compared to high-transport years (Fig. 3), as reflected in slope selection ratios of $\mathrm{B}_{2}=0.44$, vs. $\mathrm{B}_{2}=0.68$, respectively (Table 7).
In the northeastern Chukchi Sea, there were no clear interannual differences in bowhead whale distribution that could be attributed to transport (Fig. 3). Bowheads were generally dispersed southwest of Point Barrow, with a few sightings north of $72^{\circ} \mathrm{N}$ only during years of high transport. Although bowheads were seen in depth regimes in proportion to survey effort (Table 8), comparatively high standardized selection ratios were calculated for coastal/ shoal $\left(B_{4}=0.69\right)$ and shelf/trough $\left(B_{2}=0.76\right)$ habitat in years of high and moderate transport, respectively (Table 9 ). Both indices were significant, with selection of shelf/ trough waters in moderate transport years more strongly so $\left(\chi^{2}=10.06, p<0.005\right)$ than selection of coastal/shoal 
TABLE 7. Alaskan Beaufort Sea depth habitat selection ratios $\left(\mathrm{w}_{\mathrm{i}}\right)$ and standardized ratios $\left(\mathrm{B}_{\mathrm{i}}\right)$ for bowhead and white whales during high, moderate, and low transport conditions. Transport ranked from Roach et al. (1995).

\begin{tabular}{|c|c|c|c|c|c|c|c|c|}
\hline \multirow[t]{2}{*}{ Transport } & \multirow[t]{2}{*}{ Depth (m) } & \multirow[t]{2}{*}{$\mathrm{pE}_{\mathrm{i}}$} & \multicolumn{3}{|c|}{ Bowhead Whales } & \multicolumn{3}{|c|}{ White Whales } \\
\hline & & & $\mathrm{o}_{\mathrm{i}}$ & $\mathrm{w}_{\mathrm{i}}$ & $\mathrm{B}_{\mathrm{i}}$ & $\mathrm{O}_{\mathrm{i}}$ & $\mathrm{w}_{\mathrm{i}}$ & $\mathrm{B}_{\mathrm{i}}$ \\
\hline High & $\begin{array}{l}>2000 \\
201-2000 \\
51-200 \\
\leq 50\end{array}$ & $\begin{array}{l}0.08 \\
0.13 \\
0.20 \\
0.59\end{array}$ & $\begin{array}{l}0.01 \\
0.02 \\
0.18 \\
0.79\end{array}$ & $\begin{array}{l}0.125 \\
0.154 \\
0.900 \\
1.339\end{array}$ & $\begin{array}{l}0.05 \\
0.06 \\
0.36 \\
0.53\end{array}$ & $\begin{array}{l}0.05 \\
0.62 \\
0.31 \\
0.02\end{array}$ & $\begin{array}{l}0.625 \\
4.769 \\
1.550 \\
0.034\end{array}$ & $\begin{array}{l}0.09 \\
0.68 \\
0.22 \\
0.01\end{array}$ \\
\hline Total & & 1.0 & 1.0 & 2.518 & 1.0 & 1.0 & 6.978 & 1.0 \\
\hline Total & & 1.0 & 1.0 & 3.110 & 1.0 & 1.0 & 5.336 & 1.0 \\
\hline Low & $\begin{array}{l}>2000 \\
201-2000 \\
51-200 \\
\leq 50\end{array}$ & $\begin{array}{l}0.12 \\
0.23 \\
0.24 \\
0.41\end{array}$ & $\begin{array}{l}0.03 \\
0.16 \\
0.25 \\
0.56\end{array}$ & $\begin{array}{l}0.250 \\
0.696 \\
1.042 \\
1.366\end{array}$ & $\begin{array}{l}0.07 \\
0.21 \\
0.31 \\
0.41\end{array}$ & $\begin{array}{l}0.23 \\
0.52 \\
0.23 \\
0.02\end{array}$ & $\begin{array}{l}1.917 \\
2.261 \\
0.958 \\
0.049\end{array}$ & $\begin{array}{l}0.37 \\
0.44 \\
0.18 \\
0.01\end{array}$ \\
\hline
\end{tabular}
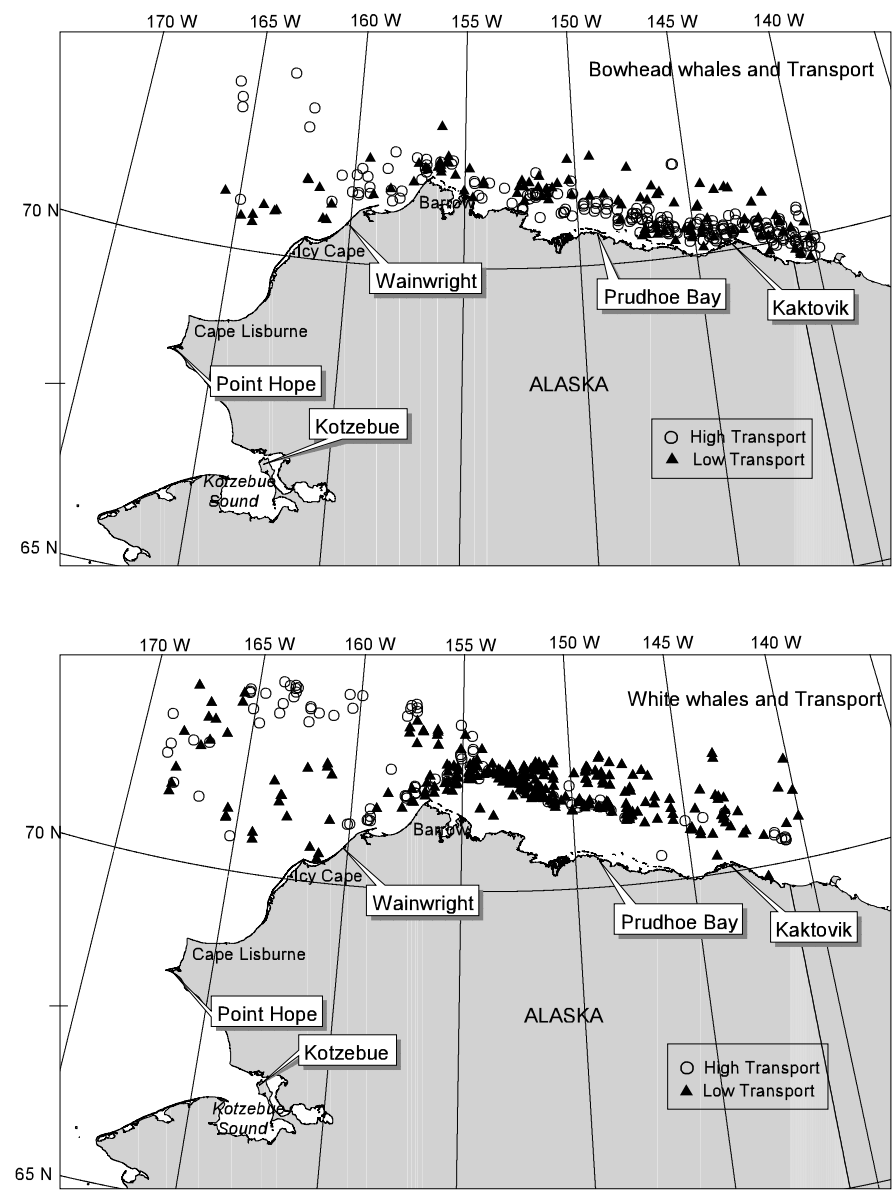

FIG. 3. Bowhead and white whale autumn distribution in low and high transport conditions.

habitat in high transport years $\left(\chi^{2}=4.91, p<0.05\right)$. The apparent selection of shelf/trough habitat in low transport years $\left(B_{2}=0.56\right)$ was not significant $\left(\chi^{2}=1.36, p<0.25\right)$.

White whales were seen more often than expected in slope habitat under all transport conditions, but signifi- cantly so in high and moderate transport years (Table 8). Standardized selection ratios reflect the strong association of white whales with slope habitat in all transport conditions, with shelf/trough waters used roughly twice as often in low-transport years (Table 9). As in all multiyear plots, white whale distribution appeared to bifurcate at about $154^{\circ} \mathrm{W}$, with one arm aligned with the axis of Barrow Canyon, and the other along the shelf axis in the northern Chukchi Sea (Fig. 3). Distribution clustered at about $72^{\circ} 30^{\prime} \mathrm{N}, 168^{\circ} \mathrm{W}$, in moderate and low transport years, was roughly associated with Hanna Sea Canyon, which cleaves the shelf at about that longitude at $73^{\circ} 30^{\prime} \mathrm{N}$.

Gray whales were seen more often than expected in coastal/shoal habitat across all transport conditions in the northern Chukchi Sea (Fig. 2, Table 8). An exceptionally high selection ratio $\left(\mathrm{B}_{4}=0.93\right)$ reflects the strong affinity of gray whales for coastal/shoal habitat in years of high transport (Table 9). Conversely, in years of moderate and low transport, gray whales were more strongly associated with shelf/trough waters $\left(B_{2}=0.68-0.69\right)$. Indeed, standardized ratios suggest that the latter habitat was selected at least twice as frequently as coastal/shoal waters during moderate and low-transport years. Notably, there were no gray whale t-SI in shelf/trough habitat during hightransport years.

\section{DISCUSSION}

This evaluation of variability of cetacean distribution and habitat selection was, of necessity, temporally narrow (autumn), but geographically broad. It reflects variability among two species that are primarily migrating with some feeding (bowhead and white whales), and one that is primarily feeding and preparing to migrate (gray whale). The study did not take into account variability in whale 
TABLE 8. Variability of bowhead whale (BH), white whale (WW), and gray whales (GW) transect sightings (t-SI) with transport rank, by depth regime, in the northern Chukchi Sea. Annual transport ranked from Roach et al. (1995).

\begin{tabular}{|c|c|c|c|c|c|c|c|c|c|}
\hline \multirow[t]{2}{*}{ Transport [years] } & \multirow[t]{2}{*}{ Depth Regime (m) } & \multirow[t]{2}{*}{ Effort $(\mathrm{t}-\mathrm{km})$} & \multicolumn{3}{|c|}{ Observed (t-SI) } & & \multicolumn{3}{|c|}{ Expected } \\
\hline & & & $\mathrm{BH}$ & WW & GW & & $\mathrm{BH}$ & WW & GW \\
\hline High & $>200$ & 610 & 0 & 6 & 0 & & 1 & 2 & 0 \\
\hline \multirow[t]{3}{*}[1982,1989,1990]{} & $51-200$ & 475 & 0 & 1 & 0 & & 1 & 2 & 0 \\
\hline & $36-50$ & 11941 & 14 & 41 & 2 & & 17 & 36 & 8 \\
\hline & $\leq 35$ & 4025 & 10 & 4 & 9 & & 5 & 12 & 3 \\
\hline \multirow[t]{3}{*}{ Total } & & 17051 & 24 & 52 & 11 & & 24 & 52 & 11 \\
\hline & & & & & & $\chi^{2}=$ & 7 & 14 & 16 \\
\hline & & & & & & $p<$ & 0.10 & 0.005 & 0.005 \\
\hline Moderate & $>200$ & 718 & 0 & 7 & 0 & & 0 & 2 & 1 \\
\hline \multirow[t]{3}{*}[1984,1985,1986,1991]{} & $51-200$ & 1395 & 3 & 3 & 10 & & 1 & 4 & 2 \\
\hline & $36-50$ & 17731 & 7 & 56 & 13 & & 8 & 52 & 27 \\
\hline & $\leq 35$ & 6313 & 2 & 10 & 17 & & 3 & 18 & 10 \\
\hline \multirow{3}{*}{ Total } & & 26157 & 12 & 76 & 40 & & 12 & 76 & 40 \\
\hline & & & & & & $\chi^{2}=$ & 4 & 16 & 45 \\
\hline & & & & & & $p<$ & 0.50 & 0.005 & 0.001 \\
\hline Low & $>200$ & 569 & 0 & 3 & 0 & & 0 & 1 & 1 \\
\hline \multirow{3}{*}[1983,1987,1988]{} & $51-200$ & 1167 & 2 & 4 & 6 & & 1 & 2 & 1 \\
\hline & $36-50$ & 14680 & 13 & 26 & 3 & & 13 & 28 & 5 \\
\hline & $\leq 35$ & 4657 & 3 & 7 & 12 & & 4 & 9 & 4 \\
\hline \multirow{3}{*}{ Total } & & 21073 & 18 & 40 & 21 & & 18 & 40 & 11 \\
\hline & & & & & & $\chi^{2}=$ & 1 & 6 & \\
\hline & & & & & & $\stackrel{n}{p}<$ & 0.90 & 0.25 & 0.001 \\
\hline
\end{tabular}

TABLE 9. Northern Chukchi Sea depth habitat selection ratios $\left(\mathrm{w}_{\mathrm{i}}\right)$ and standardized ratios $\left(\mathrm{B}_{\mathrm{i}}\right)$ for bowhead, white, and gray whales during high, moderate, and low transport conditions. Transport ranked from Roach et al. (1995).

\begin{tabular}{|c|c|c|c|c|c|c|c|c|c|c|c|}
\hline \multirow[t]{2}{*}{ Transport } & \multirow[t]{2}{*}{ Depth (m) } & \multirow[t]{2}{*}{$\mathrm{pE}_{\mathrm{i}}$} & \multicolumn{3}{|c|}{ Bowhead Whales } & \multicolumn{3}{|c|}{ White Whales } & \multicolumn{3}{|c|}{ Gray Whales } \\
\hline & & & $\mathrm{O}_{\mathrm{i}}$ & $\mathrm{w}_{\mathrm{i}}$ & $\mathrm{B}_{\mathrm{i}}$ & $\mathrm{O}_{\mathrm{i}}$ & $\mathrm{w}_{\mathrm{i}}$ & $\mathrm{B}_{\mathrm{i}}$ & $\overline{o_{i}}$ & $\mathrm{w}_{\mathrm{i}}$ & $\mathrm{B}_{\mathrm{i}}$ \\
\hline \multirow[t]{4}{*}{ High } & $>200$ & 0.04 & 0 & 0 & 0 & 0.11 & 2.750 & 0.56 & 0 & 0 & 0 \\
\hline & $51-200$ & 0.03 & 0 & 0 & 0 & 0.02 & 0.667 & 0.14 & 0 & 0 & 0 \\
\hline & $36-50$ & 0.70 & 0.58 & 0.829 & 0.31 & 0.79 & 1.129 & 0.23 & 0.18 & 0.257 & 0.07 \\
\hline & $\leq 35$ & 0.23 & 0.42 & 1.826 & 0.69 & 0.08 & 0.348 & 0.07 & 0.82 & 3.565 & 0.93 \\
\hline Total & & 1.0 & 1.0 & 2.655 & 1.0 & 1.0 & 4.894 & 1.0 & 1.0 & 3.822 & 1.0 \\
\hline \multirow[t]{4}{*}{ Moderate } & $>200$ & 0.03 & 0 & 0 & 0 & 0.09 & 3.000 & 0.55 & 0 & 0 & 0 \\
\hline & $51-200$ & 0.05 & 0.25 & 5.000 & 0.76 & 0.04 & 0.800 & 0.15 & 0.25 & 5.000 & 0.69 \\
\hline & $36-50$ & 0.68 & 0.58 & 0.853 & 0.13 & 0.74 & 1.088 & 0.20 & 0.32 & 0.471 & 0.06 \\
\hline & $\leq 35$ & 0.24 & 0.17 & 0.708 & 0.11 & 0.13 & 0.542 & 0.10 & 0.43 & 1.792 & 0.25 \\
\hline Total & & 1.0 & 1.0 & 6.561 & 1.0 & 1.0 & 5.430 & 1.0 & 1.0 & 7.263 & 1.0 \\
\hline \multirow[t]{4}{*}{ Low } & $>200$ & 0.03 & 0 & 0 & 0 & 0.08 & 2.667 & 0.42 & 0 & 0 & 0 \\
\hline & $51-200$ & 0.05 & 0.11 & 2.200 & 0.56 & 0.10 & 2.000 & 0.31 & 0.29 & 5.800 & 0.68 \\
\hline & $36-50$ & 0.70 & 0.72 & 1.029 & 0.26 & 0.65 & 0.929 & 0.15 & 0.14 & 0.200 & 0.02 \\
\hline & $\leq 35$ & 0.22 & 0.17 & 0.708 & 0.18 & 0.17 & 0.773 & 0.12 & 0.57 & 2.591 & 0.30 \\
\hline Total & & 1.0 & 1.0 & 3.937 & 1.0 & 1.0 & 6.369 & 1.0 & 1.0 & 8.591 & 1.0 \\
\hline
\end{tabular}

distribution that may be caused by underwater noise from offshore oil and gas activities in the Alaskan Beaufort Sea because those changes to whale movements appear to occur at ranges of roughly 10 to $50 \mathrm{~km}$, and to be relatively short-term in nature (Richardson, 2000). That is not to say that bowhead whale migratory behavior is unaffected by noise, but rather that those effects will be dampened out by the broad geographic and temporal scale of presentation here. Lastly, two caveats particular to this study must be kept in mind when interpreting the results: (1) sea ice seems to bias detection of bowhead whales (negatively) and white whales (positively) during aerial surveys; and (2) the comparative bathymetric uniformity of the Chukchi Sea causes depth to be a poor delimiter of habitat there.
Given these qualifications, this description of cetacean habitat variability provides a basis for future survey designs, which can incorporate at the outset plans to account for sampling bias and to assess a suite of oceanographic parameters.

\section{Variability of Habitat Selection with Oceanographic Conditions}

Bowhead whales displayed greater variability in habitat selection than either white or gray whales. In the Alaskan Beaufort Sea, selection ratios suggest that bowheads occupied inner and outer shelf habitat in years of light and moderate ice, but shifted to outer shelf and slope habitat in 
years of heavy ice conditions. In the northern Chukchi Sea, bowheads maintained their association with shallow, coastal waters in light ice years, and with shelf/trough (i.e., outer shelf) depths in heavy ice conditions. No shift in bowhead habitat could be attributed to transport variability in the Alaskan Beaufort Sea. However, in the northern Chukchi Sea, bowheads selected coastal/shoal habitats in high-transport years, and shelf/trough waters in years of moderate transport. In contrast, white whales selected slope waters in both the Alaskan Beaufort and northern Chukchi Seas under all ice cover and transport conditions. Gray whale habitat selection appeared more strongly influenced by transport than by ice cover conditions. During high-transport conditions, gray whales occupied coastal/ shoal habitats in the northern Chukchi Sea nearly to the exclusion of all other habitats. Conversely, they selected shelf/trough habitat over twice as often as coastal/shoal habitat during years of moderate and low transport. Ice conditions did not foster differences in gray whale habitat selection: ratios derived for light and heavy ice years are similar. During moderate ice years, gray whales selected shelf/trough habitat over coastal/shoal feeding areas by nearly three to one.

\section{Variability of Habitat Selection and Trophic Levels}

Cetacean habitats in the Alaskan Arctic can be linked to bathymetry, which in turn channels major currents and therefore advection of nutrients and prey. In addition, certain bathymetric domains (i.e., shelf and slope) are generally associated with comparatively high primary and secondary production. Food webs in the northern Bering and Chukchi Seas are strongly influenced by advection, as the downstream end of the immense primary production pool along the Bering Sea shelf edge, referred to as the "Green Belt" by Springer et al. (1996). Specifically, Coachman (1993) describes the seasonal flow field in the Chirikov Basin that transports nutrients to this highly productive region, which then supports an extremely dense benthic amphipod community (Highsmith and Coyle, 1990, 1992). In the Alaskan Beaufort Sea, production over shelf and slope waters may take on a more dominant role in terms of cetacean prey availability. For example, Conover (1988) describes the importance of slope waters for overwintering Calanus spp. in the Arctic, and Lowry and Frost (1981) report that larger Calanus-eating arctic cod (Boreogadus saida) are more common in water more than $100 \mathrm{~m}$ deep than in shallower water. Thus, both advection-based and production-based food webs can be coupled to bathymetry in the Alaskan Arctic.

Gray whales best exemplify cetacean habitat selection and variability linked to transport. Gray whales forage primarily on benthic infauna (Stoker, 1981, in press; Nerini, 1984), dense standing stocks of which are maintained by pelagic-benthic coupling of advected nutrients (Grebmeier et al., 1989; Grebmeier and Barry, 1991). Although this behavior is not as well described for the northern Chukchi as for the Chirikov Basin, gray whales routinely prey on dense patches of benthic amphipods that occur along the coast between Icy Cape and Barrow and in isolated offshore shoal areas (Feder et al., 1994). Gray whales selected these areas, to the virtual exclusion of other habitats, in years of high transport when productivity was probably enhanced by the advection of nutrients. Conversely, in moderate and low transport years, gray whales more commonly selected shelf/trough areas, where bathymetrically directed currents may provide migration cues to southbound whales.

Bowhead whale habitat selection varied with ice conditions across the Alaskan Arctic, and with transport in the northern Chukchi Sea. In years of light and moderate ice, bowheads selected inner shelf and coastal/shoal waters, where dense patches of zooplankton can be encountered (e.g., Fissel et al., 1987; Conover, 1988; Schoenherr and Wartzok, 1991). Specifically, Griffiths et al. (1987) reported that zooplankton patches dominated by Calanus spp. and Limnocalanus macrurus were common between shore and the $50 \mathrm{~m}$ isobath in the eastern Alaskan Beaufort Sea. In heavy ice years, bowheads occurred principally in outer shelf and slope waters, the domain of the Beaufort Undercurrent. Northerly winds, common during years of heavy ice cover, are not conducive to the type of hydrographic stratification associated with bowhead feeding areas (Bradstreet et al., 1987; Fissel et al., 1987). Thus bowheads may not shift 'onshore' during autumns of heavy ice for lack of foraging opportunities there. As in the case of gray whales, bowhead use of shelf/trough habitat in the northern Chukchi Sea during heavy ice conditions may be related to migratory cues provided by currents channeled there.

Transport may play the dominant role in bowhead feeding opportunities in the northern Chukchi Sea. Bowheads have been observed feeding just east of Point Barrow in some autumns (Ljungblad et al., 1986; Moore and Clarke, 1992), and the stomach contents of whales landed by hunters indicate the most common prey is the euphausiid Thysanoessa raschii (Lowry, 1993). Niebauer and Schell (1993) and Springer et al. (1989) described the euphausiids $T$. raschii and T. inermis as a dominant component of the zooplankton advected through the Bering Strait each summer. These euphausiids mature over the summer as they are transported north, and they can provide prime food for bowheads returning to the northern Chukchi during the autumn migration. In addition, bowhead foraging may be enhanced by the entrainment of euphausiids in an eddy that sometimes develops just northeast of Point Barrow (D'Asaro, 1988).

White whale habitat selection did not vary with ice conditions or transport. White whales selected slope or basin depths in all oceanographic conditions, indicating their strong affiliation with off-shelf habitat. Indeed, the boundaries of the study area probably severely truncated the northern distribution and habitat selection described for white whales. Recent data on white whale movements 
from satellite-tagged whales provide dramatic evidence of their use of the Beaufort slope and basin habitat (Richard et al., in press; Suydam et al., in press). Clearly these whales are capable of far-ranging movements deep into the Canadian basin, far beyond the area surveyed during the years of this study.

Offshore of northern Alaska, white whales feed primarily on arctic cod (80\% of diet), with other fishes, cephalopods, and shrimps making up the rest (Seaman et al., 1982; Frost and Lowry, 1984). Cod feed primarily on planktonic copepods and amphipods, ice-associated amphipods, and epibenthic crustacea (Bradstreet et al., 1986; Lønne and Gulliksen, 1989). Because arctic cod is not a commercial species, few data are available on its distribution and relative abundance. Lowry and Frost (1981) described the ecological importance of arctic cod offshore of northern Alaska. On the basis of data from otter trawl collections, they reported that cod were most abundant in the northeastern Chukchi and western Beaufort Seas, where they prey predominantly on calanoid copepods. In a study of arctic cod use of coastal waters and lagoons in the Beaufort Sea, Craig et al. (1982) reported that in late summer, cod abundance increased near shore; but in winter, the highest catch rate was $175 \mathrm{~km}$ offshore (depth not given). Although cod were noted as "abundant" offshore throughout the year, their occurrence was highly variable.

In the Alaskan Arctic, white whales routinely selected slope and basin habitat, where ice cover is often moderate to heavy and where (presumably) comparatively high secondary production results in the availability of arctic cod and perhaps other prey. Elsewhere, cod are often associated with ice (Lønne and Gulliksen, 1989), although they are also found in ice-free areas, where they sometimes appear in large schools (up to $130000 \mathrm{~m}^{2}$ surface area containing $\sim 4 \times 10^{8}$ fish (Welch et al., 1993). The continental slope and ice edges are often sites of oceanic upwelling, and therefore of high fish production (Dunbar, 1981). As in the Canadian Arctic (Bradstreet and Cross, 1982), white whales offshore of Alaska likely select this habitat for the enhanced feeding opportunities provided by augmented primary and secondary productivity.

The response of each species to varied oceanographic conditions can be interpreted with regard to trophic dynamics. Gray whales were strongly associated with coastal/ shoal feeding areas in the northern Chukchi Sea when transport at Bering Strait was high. In the Alaskan Beaufort Sea, bowheads remained in slope waters during autumns when heavy ice conditions may have curtailed feeding opportunities on the shelf, which they exploit in years of light and moderate ice. White whales remained in slope waters across the Alaskan Arctic, where upwelling creates comparatively high secondary productivity every year. This rudimentary model provides a basis for hypotheses regarding Arctic cetaceans' responses to climate change. For example, climate change that intensifies transport may enhance gray whale feeding habitat; while reduction in ice cover may expand foraging opportunities for bowheads, but reduce them for white whales. Clearly, additional research on prey availability, whale foraging dynamics, and population status is required to test these ideas and to refine our understanding of the cetaceans' role in the ecology of the Alaskan Arctic.

\section{ACKNOWLEDGEMENTS}

Funding for the aerial surveys was provided by the U.S. Minerals Management Service, Alaska OCS Region. The manuscript is a revised version of Moore (1997: Chapter 4) and was improved by comments from members of my dissertation committee at SIO: Jack Bradbury, Dave Checkley, Paul Dayton, Douglas DeMaster, Paul Smith, and Jim Swift. The final version of the paper was further improved by the thoughtful comments of John Craighead George and two anonymous reviewers. Janet Clarke supported all aspects of the fieldwork and much of the analytical work presented here. Kristin Laidre provided 'new and improved' GIS-generated distribution maps. I thank all these people, as well as friends and family who have borne up under my glacially paced presentation of this work over the last decade.

\section{REFERENCES}

AAGAARD, K. 1984. The Beaufort undercurrent. In: Barnes, P.W., Schell, D.M., and Reimnitz, E., eds. The Alaska Beaufort Sea: Ecosystems and environments. Orlando, Florida: Academic Press Inc. 47-71.

AAGAARD, K., and ROACH, A.T. 1990. Arctic ocean-shelf exchange: Measurements in Barrow Canyon. Journal of Geophysical Research 95(C10):18,163-18,175.

AAGAARD, K., ROACH, A.T., and SCHUMACHER, J.D. 1985. On the wind-driven variability of the flow through Bering Strait. Journal of Geophysical Research 90:7213-7221.

AAGAARD, K., DARBY, D., FALKNER, K., FLATO, G., GREBMEIER, J., MEASURES, C., and WALSH, J. 1999. Marine science in the Arctic: A strategy. Fairbanks, Alaska: Arctic Research Consortium of the United States. 84 p.

AINLEY, D.G., and DeMASTER, D.P. 1990. The upper trophic levels in polar marine ecosystems. In: Smith, W.O., Jr., ed. Polar oceanography, Part B: Chemistry, biology and geology. San Diego, California: Academic Press, Inc. 599-630.

BJORNSSON, H., MYSAK, L.A., and BROWN, R.D. 1995. On the interannual variability of precipitation and runoff in the Mackenzie drainage basin. Climate Dynamics 12:67-76.

BRADSTREET, M.S.W., and CROSS, W.E.. 1982. Trophic relationships at High Arctic ice edges. Arctic 35(1):1-12.

BRADSTREET, M.S.W., FINLEY, K.J., SEKERAK, A.D., GRIFFITHS, W.B., EVANS, C.R., FABIJAN, M.F., and STALLARD, H.E. 1986. Aspects of the feeding biology of arctic cod (Boreogadus saida) and its importance in arctic marine food chains. Ottawa, Ontario: Canadian Technical Report of Fisheries and Aquatic Science No. 1491.

BRADSTREET, M.S.W., THOMSON, D.H., and FISSEL, D.B. 1987. Zooplankton and bowhead whale feeding in the Canadian 
Beaufort Sea, 1986. Unpubl. report by LGL Limited. Available at Indian and Northern Affairs Canada, Terrasses de la Chaudière, 10 Wellington, North Tower, Hull, Quebec K1A 0H4, Canada.

BUCKLAND, S.T., ANDERSON, D.R., BURNHAM, K.P., and LAAKE, J.L. 1993. Distance sampling. New York: Chapman \& Hall.

CHAPMAN, C.F. 1977. Piloting, seamanship and small boat handling. New York: Hearst Books.

COACHMAN, L.K. 1993. Flow field in the Chirikov Basin. Continental Shelf Research 13(5/6):481-508.

COACHMAN, L.K., and AAGAARD, K. 1988. Transports through Bering Strait: Annual and interannual variability. Journal of Geophysical Research 93(C12):15,535-15,539.

CONOVER, R.J. 1988. Comparative life histories in the genera Calanus and Neocalanus in high latitudes of the Northern Hemisphere. Hydrobiologia 167/168:127-142.

CRAIG, P.C., GRIFFITHS, W.B., HALDORSON, L., and McELDERRY, H. 1982. Ecological studies of arctic cod (Boreogadus saida) in Beaufort Sea coastal waters, Alaska. Canadian Journal of Fishery and Aquatic Science 39:395-405.

D'ASARO, E.A. 1988. Generation of mesoscale vortices: A new mechanism. Journal of Geophysical Research 93(C6): $6685-6693$.

DeMASTER, D.P., and DAVIS, R. 1995. Workshop on the use of ice-associated seals in the Bering and Chukchi Seas as indicators of environmental change. Report of the Workshop on IceAssociated Seals held 29-31 March 1994 at the National Marine Mammal Laboratory, NOAA, Seattle, Washington. 10 p.

DUNBAR, M. 1981. Physical causes and biological significance of polynyas and other open water in sea ice. In: Stirling, I., and Cleator, H., eds. Polynyas in the Canadian Arctic. Canadian Wildlife Service Occasional Paper 45. 29-43.

FEDER, H.M., NAIDU, A.S., JEWETT, S.C., HAMEEDI, J.M., JOHNSON, W.R., and WHITLEDGE, T.E. 1994. The northeastern Chukchi Sea: Benthos-environmental interactions. Marine Ecology Progress Series 111:171-190.

FISSEL, D.B., MARKO, J.R., BIRCH, J.R., BORSTAD, G.A., TRUAX, D.N., and KERR, R. 1987. Water mass distribution. In: Richardson, W.J., ed. Importance of the eastern Alaskan Beaufort Sea to feeding bowhead whales, 1985-86. OCS Study MMS-87-0037. Final Report to the U.S. Minerals Management Service, Alaska OCS Region. 11-134.

FORNEY, K.A., BARLOW, J., and CARRETTA, J.V. 1995. The abundance of cetaceans in California waters. Part II: Aerial surveys in winter and spring of 1991 and 1992. Fishery Bulletin 93:15-26.

FROST, K.J., and LOWRY, L.F. 1984. Trophic relationships of vertebrate consumers in the Alaskan Beaufort Sea. In: Barnes, P.W., Schell, D.M., and Reimnitz, E., eds. The Alaska Beaufort Sea: Ecosystems and environments. Orlando, Florida: Academic Press Inc. 381-401.

GREBMEIER, J.M., and BARRY, J.P. 1991. The influence of oceanographic processes on pelagic-benthic coupling in polar regions: A benthic perspective. Journal of Marine Systems 2:495-518.

GREBMEIER, J.M., FEDER, H.M., and McROY, C.P. 1989. Pelagic-benthic coupling on the shelf of the northern Bering and
Chukchi Seas. II. Benthic community structure. Marine Ecology Progressive Series 51:253-268.

GRIFFITHS, W.B., THOMSON, D.H., and JOHNSON, G.E. 1987. Zooplankton and hydroacoustics. In: Richardson, W.J., ed. Importance of the eastern Alaskan Beaufort Sea to feeding bowhead whales, 1985-86. OCS Study MMS-87-0037. Final Report to the U.S. Minerals Management Service, Alaska OCS Region. 135-256.

HIGHSMITH, R.C., and COYLE, K.O. 1990. High productivity of northern Bering Sea amphipods. Nature 344:8662-8664.

. 1992. Productivity of arctic amphipods relative to gray whale energy requirements. Marine Ecology Progress Series 83:141- 150 .

JOHNSON, W.R. 1989. Current response to wind in the Chukchi Sea: A regional coastal upwelling event. Journal of Geophysical Research 94(C2):2057-2064.

LJUNGBLAD, D.K., MOORE, S.E., and CLARKE, J.T. 1986. Assessment of bowhead whale (Balaena mysticetus) feeding patterns in the Alaskan Beaufort and northeastern Chukchi Seas via aerial surveys, Fall 1979-84. Report of the International Whaling Commission 36:265-272.

LØNNE, O.J., and GULLIKSEN, B. 1989. Size, age and diet of polar cod, Boreogadus saida (Lepechin 1773), in ice covered waters. Polar Biology 9:187-191.

LOWRY, L.F. 1993. Foods and feeding ecology. In: Burns, J.J., Montague, J., and Cowles, C., eds. The bowhead whale. The Society for Marine Mammalogy, Special Publication No. 2. Lawrence, Kansas: Allen Press Inc. 201-238.

LOWRY, L.F., and FROST, K.J. 1981. Distribution, growth and foods of arctic cod (Boreogadus saida) in the Bering, Chukchi, and Beaufort Seas. Canadian Field-Naturalist 95:186-191.

MANLY, B.F.J., McDONALD, L.L., and THOMAS, D.L. 1993. Resource selection by animals: Statistical design and analysis for field studies. New York: Chapman and Hall.

MARSH, H., and SINCLAIR, D.F. 1989. Correcting for visibility bias in strip transect aerial surveys of aquatic fauna. Journal of Wildlife Management 53(4):1017-1024.

MARTIN, S., MUNOZ, E., and DRUCKER, R. 1997. Recent observations of a spring-summer surface warming over the Arctic Ocean. Geophysical Research Letters 24(10): $1259-1262$.

MASLANIK, J.A., SERREZE, M.C., and BARRY, R.G. 1996. Recent decreases in Arctic summer ice cover and linkages to atmospheric circulation anomalies. Geophysical Research Letters 23(13): 1677-1680.

MOORE, S.E. 1997. Cetacean habitats in the Alaskan Arctic. Ph.D. Dissertation, University of California at San Diego, Scripps Institution of Oceanography. 318 p.

MOORE, S.E., and CLARKE, J.T. 1992. Patterns of bowhead whale distribution and abundance near Barrow, Alaska, in Fall 1982 - 1989. Marine Mammal Science 8(1):27-36.

MOORE, S.E., and DeMASTER, D.P. 1997. Cetacean habitats in the Alaskan Arctic. Journal of Northwest Atlantic Fishery Science 22:55-69.

MOORE, S.E., DeMASTER, D.P., and DAYTON, P.K. 2000. Cetacean habitat selection in the Alaskan Arctic during summer and autumn. Arctic 53(4):432-447. 
MUENCH, R.D., PEASE, C.H., and SALO, S.A. 1991. Oceanographic and meteorological effects on autumn sea ice distribution in the western Arctic. Annals of Glaciology 15: $231-247$.

MYSAK, L.A., and MANAK, D.K. 1989. Arctic sea ice extent and anomalies, 1953-1984. Atmosphere-Ocean 27(2):376-405.

NAVY/NOAA. 1992. United States Navy-National Oceanographic and Atmospheric Administration Joint Ice Center: Seasonal Outlook Western Arctic Ice, 1992. Prepared by Naval Polar Oceanography Center for Naval Oceanography Command. Available at the Stennis Space Center, Mississippi 39529, U.S.A.

NERINI, M.K. 1984. A review of gray whale (Eschrichtius robustus) feeding ecology. In: Jones, M.L., Swartz, S.L., and Leatherwood, S., eds. The gray whale. Orlando, Florida: Academic Press, Inc. $423-450$.

1988. Effects of El Niño-Sourthern Oscillation (ENSO) and North Pacific weather patterns on interannual variability in the subarctic Bering Sea. Journal of Geophysical Research 93:5051-5068.

NIEBAUER, H.J., and DAY, R.H., 1989. Causes of interannual variability in the sea ice cover of the eastern Bering Sea. GeoJournal 18(1):45-59.

NIEBAUER, H.J., and SCHELL, D.M. 1993. Physical environment of the Bering Sea population. In: Burns, J.J., Montague, J., and Cowles, C., eds. The bowhead whale. The Society for Marine Mammalogy, Special Publication No. 2. Lawrence, Kansas: Allen Press Inc. 23-43.

OLIVER, J.S., and SLATTERY, P.N. 1985. Destruction and opportunity on the sea floor: Effects of gray whale feeding. Ecology 66(6):1965-1975.

OVERLAND, J.E., and ROACH, A.T. 1987. Northward flow in the Bering and Chukchi Seas. Journal of Geophysical Research 92:7097-7105.

OVERPECK, J., HUGHEN, K., HARDY, D., BRADLEY, R., CASE, R., DOUGLAS, M., FINNEY, B., GAJEWSKI, K., JACOBY, G., JENNINGS, A., LAMOUREUX, S., LASCA, A., MACDONALD, G. MOORE, J., RETELLE, M., SMITH, S., WOLFE, A., and ZIELINSKI, G. 1997. Arctic environmental changes of the last four centuries. Science 278:1251-1256.

PAQUETTE, R.G., and BOURKE, R.H. 1981. Ocean circulation and fronts as related to ice melt-back in the Chukchi Sea. Journal of Geophysical Research 86(C5):4215-4230.

RICHARD, P.R., MARTIN, A.R., and ORR, J.R. In press. Summer and autumn movements of belugas of the eastern Beaufort sea stock. Arctic.

RICHARDSON, W.J., ed. 2000. Marine mammal and acoustical monitoring of Western Geophysical's open-water seismic program in the Alaska Beaufort Sea, 1999. LGL Report TA23134. Available from NOAA/NMFS Alaska Region, 222 W. 7th Ave., Anchorage, Alaska 99513, U.S.A. 142 p.

ROACH, A.T., AAGAARD, K., PEASE, C.H., SALO, S.A., WEINGARTNER, T., PAVLOV, V., and KULAKOV, M. 1995. Direct measurements of transport and water properties through the Bering Strait. Journal of Geophysical Research 100 (C9):18,443-18,457.
ROGERS, J.C. 1978. Meteorological factors affecting inter-annual variability of summertime ice extent in the Beaufort Sea. Monographs Weather Review 106(6):890-897.

SCHOENHERR, J.R., and WARTZOK, D. 1991. Prey distribution of feeding bowheads during the fall migration in the Beaufort Sea. Abstract, Tenth Biennial Meeting of the Biology of Marine Mammals. 43.

SEAMAN, G.A., LOWRY, L.F., and FROST, K.J. 1982. Foods of belukha whales (Delphinapterus leucas) in western Alaska. Cetology 44:1-19.

SMITH, W.O., Jr., and NELSON, D.M.. 1985. Phytoplankton bloom produced by a receding ice edge in the Ross Sea: Spatial coherence with the density field. Science 227:163-166.

SMITH, W.O., Jr., and SAKSHAUG, E. 1990. Polar phytoplankton. In: Smith, W.O., Jr., ed. Polar oceanography Part B: Chemistry, biology and geology. San Diego: Academic Press, Inc. $477-525$.

SMITH, S.L., and SCHNACK-SCHIEL, S.B. 1990. Polar zooplankton. In: Smith, W.O., Jr., ed. Polar oceanography Part B: Chemistry, biology and geology. San Diego: Academic Press, Inc. 527-598.

SPRINGER, A.M., McROY, C.P., and TURCO, K.R. 1989. The paradox of pelagic food webs in the northern Bering Sea-II. Zooplankton communities. Continental Shelf Research 9: 359-386.

SPRINGER, A.M., McROY, C.P., and FLINT, M.V. 1996. The Bering Sea Green Belt: Shelf-edge processes and ecosystem production. Fisheries Oceanography 5(3/4):205-223.

STIRLING, I., LUNN, N.J., and IACOZZA, J. 1999. Long-term trends in the population ecology of polar bears in the western Hudson Bay in relation to climate change. Arctic 52(3): 294-306.

STOKER, S.W. 1981. Benthic invertebrate macrofauna of the eastern Bering/Chukchi continental shelf. In: Hood, D.W., and Calder, J.A., eds. The eastern Bering Sea shelf: Oceanography and resources, Vol. 2. Seattle: University of Washington Press. 1069-1090.

- In press. Distribution and carrying capacity of gray whale food resources in the northern Bering and Chukchi Seas. Journal of Cetacean Research and Management, Special Issue 2.

SUYDAM, R.S., LOWRY, L.F., FROST, K.J., O'CORRYCROWE, G.M., and PIKOK, D., Jr. In press. Satellite tracking of eastern Chukchi Sea beluga whales into the Arctic Ocean. Arctic.

TYNAN, C.T., and DeMASTER, D.P. 1997. Observations and predictions of Arctic climate change: Potential effects on marine mammals. Arctic 50(4):308-322.

WELCH, H.E., CRAWFORD, R.E., and HOP, H. 1993. Occurrence of arctic cod (Boreogadus saida) schools and their vulnerability to predation in the Canadian High Arctic. Arctic 46(4): $331-339$.

ZEH, J.E., CLARK, C.W., GEORGE, J.C., WITHROW, D., CARROLL, G.M., and KOSKI, W.R. 1993. Current population size and dynamics. In: Burns, J.J., Montague, J., and Cowles, C., eds. The bowhead whale. The Society for Marine Mammalogy, Special Publication No. 2. Lawrence, Kansas: Allen Press Inc. 409-489. 